\title{
Prototype Sistem Pembiayaan Berbasis MFINWEB pada PT. Mandala Finance
}

\author{
Sarwindah $^{\# 1}$, Marinii ${ }^{\# 2}$ \\ ${ }^{\#}$ Program Studi Bisnis Digital Fakultas Ekonomi Bisnis, ${ }^{2}$ Program Studi Sistem Informasi Fakultas Teknologi \\ Informatika , ISB Atma Luhur \\ 1indah_syifaeatmaluhur.ac.id \\ 2arinimarini44@atmaluhur.ac.id
}

\begin{abstract}
Abstrak
PT Mandala Multi Finance merupakan perusahan leasing yang bergerak dibidang jasa kredit motor bagi pemohon kredit dan mengambil keuntungan dari pembayaran bunga kredit. PT.Mandala merupakan perusahaan yang memegang teguh komitmen untuk memberikan pelayanan terbaik terhadap konsumen dan mitra bisnis, melalui pelayanan optimal yang didukung oleh pengelolaan sumber daya manusia yang terarah, terpadu dan berkesinambungan, Seorang OPS (Oprationals) diharapkan untuk bekerja cepat dan teliti dalam menginput banyaknya data pemohon kredit yang masuk sehingga tidak menutup kemungkinan terjadi kesalahan-kesalan, seperti kesalahan perhitungan, kesalahan membaca data, dan lain-lain. Dengan iti ketersediaan infrastruktur yang memadai sangat di butuhkan Seperti system yang terkomputerisasi seperti MFINWEB, Dalam penelitian ini Sebuah sistem MFINWEB merupakan pilihan cukup efisien dan tepat untuk membantu penginputan data pemohon kredit dimana sistem dirancang menggunakan bahasa pemograman PHP dan database Mysql dengan metode pengembangan perangkat lunak System Development Life Cycle (SDLC) yang memiliki tahapan pengembangan yaitu Tahapan Analisa Kebutuhan Sistem, Tahapan Perancangan Sistem, Tahapan Desain Sistem, dan Tahapan Implementasi Sistem. Tujuan dari penelitian ini adalah terciptanya sebuah sistem yang dapat membantu OPS (Opratinoals) Marketing dalam kegiatan Proses Kerja terutama penginputan data konsumen yang akan mengajukan pinjaman dana. Hasil dari rancangan sistem MFINWEB yang didapat adalah program aplikasi yang dapat diintegrasikan dengan web dan Prototype yang dibangun telah berhasil membantu OPS (Oprationals) Mandala Multifinance dalam Penginputan MAP berbasis Web.
\end{abstract}

\section{Prototype of MFINWEB-Based Financing System at PT. Mandala Finance}

\begin{abstract}
PT Mandala Multi Finance is a leasing company engaged in credit services for loan applicants and take advantage of loan interest payments. PT. Mandala is a company that upholds a commitment to provide the best service to consumers and business partners, through optimal services supported by directed, integrated and sustainable An OPS (Oprational) is expected to work quickly and thoroughly in inputting the amount of incoming credit applicant data so that it does not close the possibility of errors, such as calculation errors, errors reading data, and others. Thus, the availability of adequate infrastructure is very much needed, such as a computerized system such as MFINWEB. In this study, a MFINWEB system is an efficient and appropriate choice to help input credit applicant data where the system is designed using the PHP programming language and Mysql database. the method of software development System Development Life Cycle (SDLC) which has stages of development, namely the System Requirement Analysis Stage, the System Design Stage, the System Design Stage, and the System Implementation Stage. The purpose of this research is to create a system that can help OPS (Opratinoals) Marketing in Work Process activities, especially inputting consumer data that will apply for a loan of funds. The results of the MFINWEB system design obtained are application programs that can be integrated with the web and the Prototype that was built has succeeded in helping OPS (Oprationals) Mandala Multifinance in Web-based MAP Input.
\end{abstract}

Keywords: Prototype, System, MFINWEB 


\section{Pendahuluan}

PT. Mandala Multi Finance merupakan perusahan leasing yang bergerak dibidang jasa kredit motor bagi pemohon kredit dan mengambil keuntungan dari pembayaran bunga kredit. PT Mandala Multifinance adalah Perusahaan leasing berdasarkan Keputusan Menteri Keuangan RI No. 323/KMK.017/1997 pada tanggal 21 Juli 1997. Berdasarkan keputusan tersebut, kegiatan usaha Perusahaan meliputi Sewa Guna Usaha, Anjak Piutang, Usaha Kartu Kredit, dan Pembiayaan Konsumen. Sampai saat ini Perusahaan memfokuskan diri pada kegiatan usaha pembiayaan konsumen, khususnya pembiayaan kendaraan roda dua. Perusahaan memegang teguh berkomitmen untuk memberikan pelayanan terbaik terhadap konsumen dan mitra bisnis, melalui pelayanan optimal yang didukung oleh pengelolaan sumber daya manusia yang terarah, terpadu dan berkesinambungan, serta ketersediaan infrastruktur yang memadai. Dalam upaya membantu OPS (Oprationals) dalam kegiatan penginputan data konsumen dalam mengajukan dana maka diperlukan sebuah system berbasis web dan berbasis komputererisasi yang dapat memberikan kemudahan dalam melakukan penginputan data konsumen berdasarkan kriteria pemohon kredit atau konsumen dengan menentukan perubahan acuan kriteria penilaian kredit seperti penghasilan (slip gaji), Jumlah Tanggungan (Kartu keluarga), Domisi (KTP).

Tujuan yang ingin dicapai pada peneltian ini adalah untuk memudahkan OPS dan marketing dalam memproses data pemohon kredit atau konsumen di PT.Mandala Multifinance. dengan mencoba memberikan solusi berupa Aplisaksi MFIN berbasis Web dan penelitian ini juga diharapkan dapat membantu bagian OPS(Oprationals) Mandala Multifinance dalam Penginputan MAP berbasis Web.

Adapun rujukan yang menjadi acuan dalam proses penelitian ini adalah dari penelitian kami sebelumnya Penunjang Keputusan Dalam Kelayakan Pemberian Kredit Motor Pada Mandala Multifinance dengan tujuan untuk membantu Credit Analyst dalam kegiatan pengambilan keputusan konsumen layak kredit. Tujuan yang ingin dicapai pada peneltian ini adalah untuk membuat sistem pendukung keputusan pemberian kelayakan kredit kepada konsumen dengan menerapkan kriteria penilaian kelayakan kredit yaitu penghasilan (slip gaji), jumlah tanggungan (kartu keluarga), domisi (KTP) disertai bobot penilaian pada setiap kriteria. Sarwindah dan Marini.

\section{A. Penelitihan Terdahulu}

Untuk melakukan pemodelan sistem / perangkat lunak secara visual digunakan UML (Unified. Modelling Language) yang digambarkan secara elektronik kombinasi dari teknologi informasi dan aktivitas orang yang menggunakan teknologi itu untuk mendukung operasi dan manajemen.[1], Dengan menggunakan model diharapkan pengembangan piranti lunak dapat memenuhi semua kebutuhanpengguna dengan lengkap dan tepat, termasuk faktor-faktor seperti scalability, robustnees, security, dansebagainya. Untuk melakukan pemodelan sistem / perangkat lunak secara visual digunakan UML (UnifiedModelling Language) yang digambarkan secara elektronik lewat sarana perangkat lunak Rational Rose [2], metode yang objektif untuk memutuskan pilihan yang cepat berdasarkan data perumahan yang mana yang sesuai dengan keinginan konsumen. Dengan mengacu kepada solusi Analytical Hierarki Process ( AHP ) dalam membantu membuat keputusan, seorang decision maker dapat mengambil keputusan tentang perumahan yang sesuai dengan yang dinginkan secara cepat dengan membandingkan semua kriteria yang ada .[3], Microsoft Visio 2007 adalah salah satu program dari Microsoft Office yang digunakan untuk membuat diagram. Visio dapat menghasilkan suatu diagram, mulai dari yang sederhana hingga yang komplek seperti activity dan use case diagram.[4], Unified Modelling Language(UML) merupakanbahasa pemodelanperangkat lunak atau sistem dengan konsep pemrograman berorientasi objek yang dapat analisa dan menjabarkan secara rinci apa yang diperlukan oleh sistem.[5], sebuah program aplikasi atau software yang merequest dokumen-dokumen dari komputer-komputer yang terkoneksi dengan internet.[6], Merancang Database merupakan persiapan program.[7], Dalam menghasilkan sebuah situs dinamis, PHP digunakan bersama-sama dengan relational-databasemanagement-system (RDBMS) untuk tempat penyimpanan data, seperti MySQL. MySQL adalah RDMS opensource yang paling populer saat ini, selain memiliki fitur database yang lengkap, multi user dan sangat cepat. MySQL sangat umum dipakai untuk aplikasi berbasis web.[8], teknologi dalam bidang komputer telah mampumemproses informasi secara akurat, tepat waktu, dan relevan.Sehingga akan sangat membantu para manajemen dalammengambil keputusan.[9], penelitian yang digunakan dalam penelitian ini bersifat deskriptif analisis, dan dilakukan melalui tahapan system develpoment yang menggunakan metode pengembangan FAST (Frame Work for the Application of System Technique) dan teknik pengembangan JAD (Joint Application Development) mengikuti tahapan-tahapan Sistem Life Cycle dengan tambahan alat-alat dan teknik yang disediakan untuk memudahkan analis dalam pelaksanaan pengembangan sistem, sehingga hasil akhir dari sistem yang dikembangkan akan mendapatkan sistem yang terstruktur dan didefinisikan dengan baik dan jelas.[10], Aplikasi web yang dibuat memberikan informasi mengenai perjalanan barang dari daerah yang satu ke daerah yang lain sehingga pihak penyedia layanan atau pemilik barang dapat menggunakan informasi tersebut (tracking), memuat berbagai informasi pengiriman terkini, memuat informasi tarif, memuat profile dan memberikan informasi lain yang berguna bagi pelanggan.[11], Sistem informasi adalah suatu sistem dalam suatu organisasi yang mempertemukan kebutuhan pengolahan transaksi harian yang mendukung berjalannya sebuah sistem.[12], prototype adalah model kerja dasar sebagai pengembangan perangkat lunak. Namun, ada 
beberapa hal yang mungkin belum diketahui tentang prototype oleh kalangan masyarakat umumnya, proses perancangan sistem dengan membentuk contoh dan standar ukuran yang akan Anda kerjakan nantinya. Jika anda memakai metode prototype, para pengembang dan pelanggan akan saling berinteraksi sampai hasil yang terbaik keluar.[13], pemrograman web dengan mudah memakai 3 bahasa pemrograman pokok, yaitu HTML5, PHP, dan JavaScript. Anda akan belajar bagaimana memanfaatkan HTML5 sebagai antarmuka awal, selanjutnya mengenal PHP untuk memberikan kemampuan pengolahan data client-server di web, lalu menggunakan JavaScript untuk memberikan sentuhan dinamis. Setiap penjelasan dilengkapi dengan contoh program dan di bagian akhir ditutup dengan pembuatan program yang melibatkan ketiganya.[14], Software engineering adalah proses analisis kebutuhan dan desain pengguna, konstruksi dan uji aplikasi yang akan memenuhi kebutuhan-kebutuhan tersebut melalui penggunaan bahasa pemrograman. Secara garis besar, software engineering bisa diartikan sebagai penerapan prinsip-prinsip teknik pengembangan perangkat lunak.[15], tujuannya untuk mendukung proses pembelajaran di sekolahan SMK Muhammadiyah 9, masalahnya begaimana memilih beberapa jenis software desain grafis seperti : Adobe Photoshop, CorelDraw, Adobe Ilustrator yang paling tepat untuk mendukung pembelajaran di SMK Muhammadiyah 9. Permasalahan pemilihan software desain grafis di SMK Muhammadiyah 9 merupakan objek penelitian,yang menghasilkan jawaban yang di inginkan yaitu software Adobe Photoshop yang menjadi prioritas dan dapat di implementasikan untuk pembelajaran di sekolahan SMK Muhammadiyah.[16], sistem yang mencakup konsep, alat, teknik, dan aplikasi mereka, dan untuk memberikan sebagian besar contoh analisis sistem dan hasil desain yang tersedia dalam buku apa pun.[17], dengan menggunakan sebuah sistem pelayanan yang berbasis mobile diharapkan sebuah kampus dapat melayani atau menampung semua komplain yang diberikan mahasiswa kepada lembaga tersebut. Sistem pelayanan akademik berbasis mobile ini adalah salah satu alternatif yang dapat dikembangkan oleh sebuah kampus untuk menjadi sarana penunjang pelayanan terhadap mahasiswa.[18], Sistem informasi Koperasi ini dirancang dengan menggunakan bahasa pemograman PHP dan untuk menggambarkan hasil analisa dan desain system digunakan teknik pemodelan terstruktur dalam bentuk DFD dan ERD. Output dari penelitian ini adalah rancangan prototype sistem informasi koperasi berbasis web pada Koperasi Unit Desa Pandan Jaya Geragai. Dengan adanya sistem informasi koperasi ini diharapkan dapat memberikan wadah berupa web yang dapat melakukan pengolahan data dengan baik dan terintegrasi, serta dapat membantu penyebaran informasi kepada semua pihak yang berkepentingan.[19].

\section{Metodologi}

Untuk mempermudah dalam pengerjaan penelitian ini, maka penulis membuatkan kerangka kerja penelitian seperti pada Gambar 1 berikut ini.

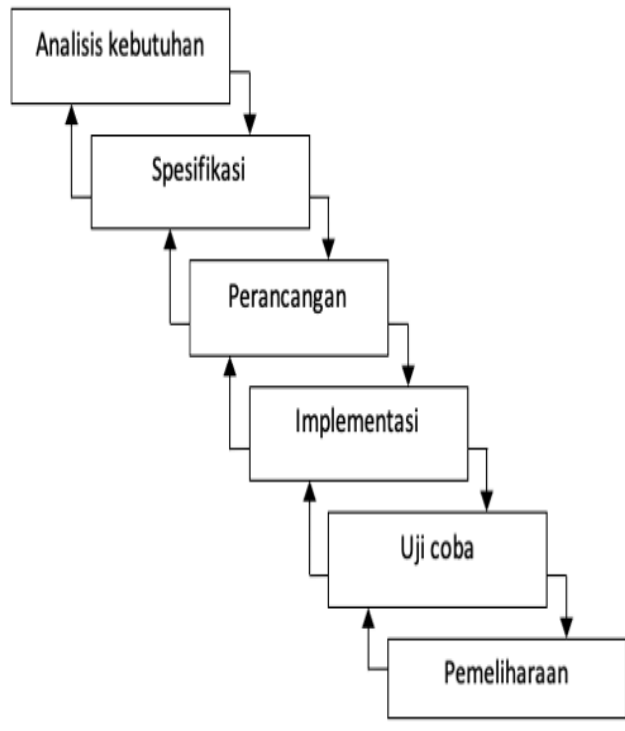

Gambar 1. Kerangka Kerja Penelitian

\section{A. Metode Pembangunan Sistem}

Setelah merumuskan Kerangka kerja maka dilanjutkan ke Tahapan Pembangunan Sistem yakni:

1) Analisa Kebutuhan Sistem

Tahap menganalisis data yang telah dikumpulkan merupakan tahap analisis berkaitan dengan proses dan data yang dibutuhkan oleh sistem. Analisis harus mencakup kebutuhan pengguna, interface, dan fungsi yang dibutuhkan. Hasil analisa yaitu berupa model sistem yang telah terstruktur.

2) Perancangan Sistem

Berdasarkan kebutuhan sistem yang telah dianalisis maka dilakukan perancangan sistem MFINWEB.

3) Implementasi Sistem

Implementasi sistem pada tahap ini, peneliti berfokus pada penerapan Prototypenya.

4) Pengujian dan Analisis

Pengujian dilakukan terhadap sistem yang telah dibangun. Pengujian ini bertujuan untuk membuktikan konsep dan sesuai kebutuhan pengguna. Pengujian kualitas dari perangkat lunak yang dibangun menggunakan pengujian Mc'Call

5) Penarikan Kesimpulan

Penarikan Kesimpulan dilakukan berdasarkan hasil analisa dan pengujian yang telah dilakukan, apakah hasil dari perancangan sistem dapat menjawab pertanyaan pada rumusan masalah dan sesuai dengan hipotesis serta kebutuhan pengguna.

\section{HASIL DAN PEMBAHASAN}

\section{A. Analisa Kebutuhan Sistem}

Tahap menganalisis berkaitan dengan proses dan data yang dibutuhkan oleh sistem. Analisis harus mencakup kebutuhan pengguna, interface, dan fungsi yang 
dibutuhkan. Hasil analisa yaitu berupa model sistem yang telah terstruktur.

1) Activity Diagram untuk data nasabah : (Lihat Gambar 2)

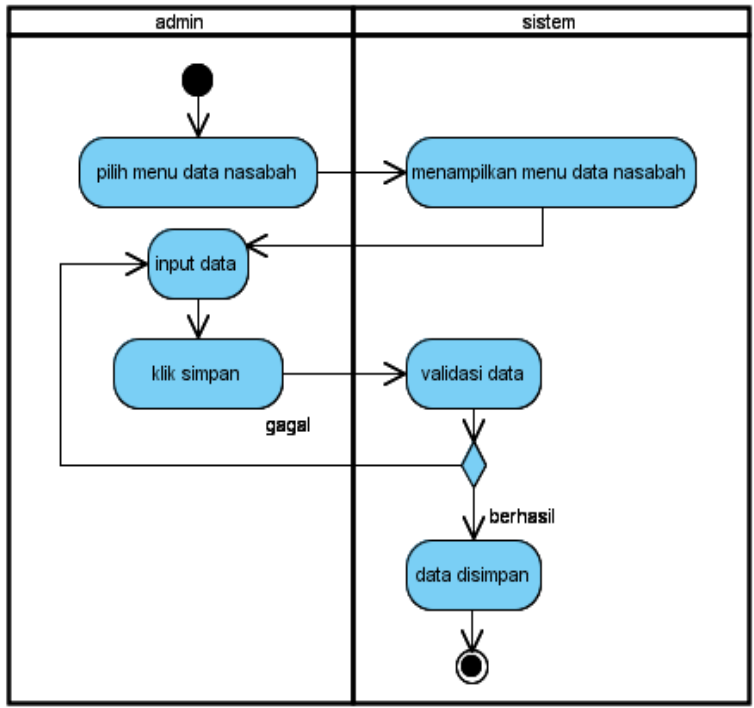

Gambar 2. Activity diagram menu data nasabah

\section{B. Perancangan Sistem}

Berdasarkan kebutuhan sistem yang telah dianalisis maka dilakukan perancangan sistem MFINWEB.

\section{1) LRS:}

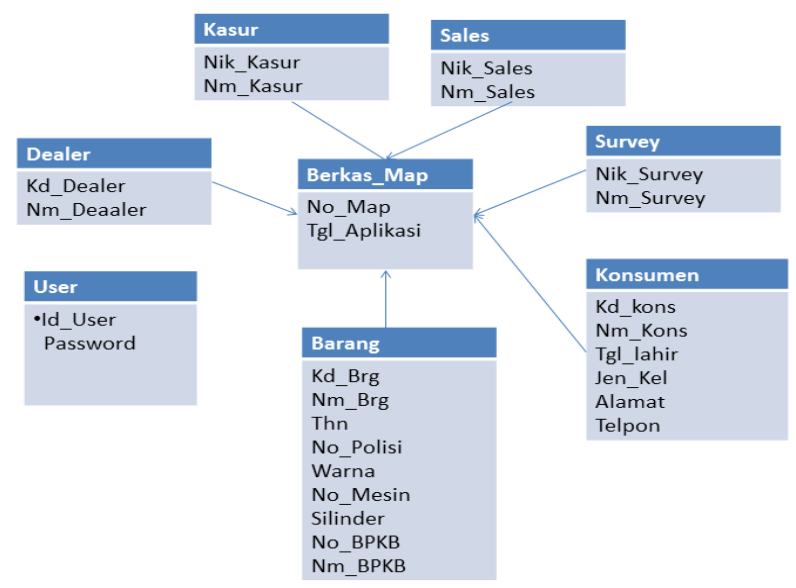

Gambar 3.Sistem usulan LRS

Berdasarkan gambar 3. Class Diagram yang diusulkan terdapat: Memiliki class yakni sebagai tabel yang didalamnya terdapat atribut-atribut. Memiliki association yakni sebagai relasi antar tabel aribut pada class dengan operasi yang sama.
2) Sistem Ususlan: (Lihat Gambar 4)

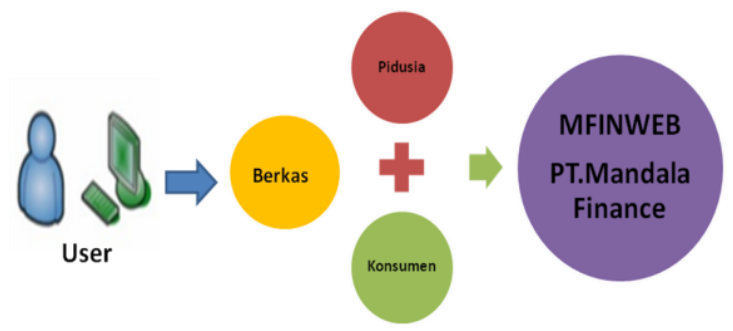

\section{Gambar 4.Sistem Usulan}

3) Teknik Analisis Data:

Teknik spesifikasi kebutuhan sistem berarti melakukan perincian mengenai apa saja yang dibutuhkan dalam pengembangan sistem dan membuat perencanaan yang berkaitan dengan proyek sistem. Analisa kebutuhan fungsional dan kebutuhan non-fungsional sistem juga diperlukan. Kebutuhan fungsional berhubungan dengan fitur perangkat lunak yang akan dibangun, integrasi sistem, pembuatan, dan transaksi. Kebutuhan non fungsional tidak secara langsung terkait pada suatu fitur yang ada dalam perangkat lunak, seperti performa sistem.

Pada penelitian ini teknik analisis sistem yang digunakan adalah mencari informasi mengenai latar belakang pada studi kasus. Proses analisis ini berguna untuk memberikan bentuk alternatif yang diajukan sebagai satu teknik pemecahan masalah. Proses analisis sistem akan menggunakan alat bantu yakni Unified Modeling Language (UML).

\section{Implementasi Sistem:}

Implementasi sistem pada tahap ini, peneliti berfokus pada penerapan Prototype-nya.

\section{1) Prototype MFINWEB}

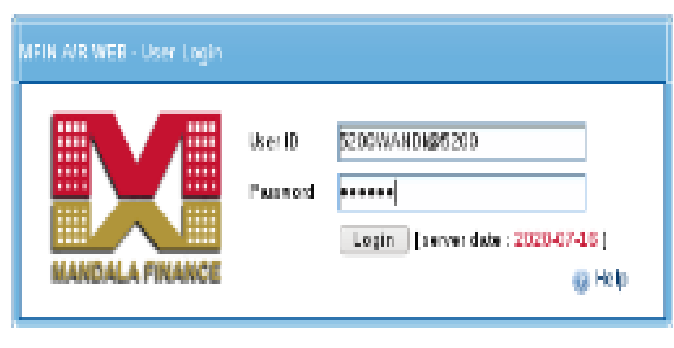

Gambar 5. Login

Antarmuka halaman login (lihat Gambar 5) merupakan halaman yang dapat diakses pengguna untuk masuk ke sistem. 


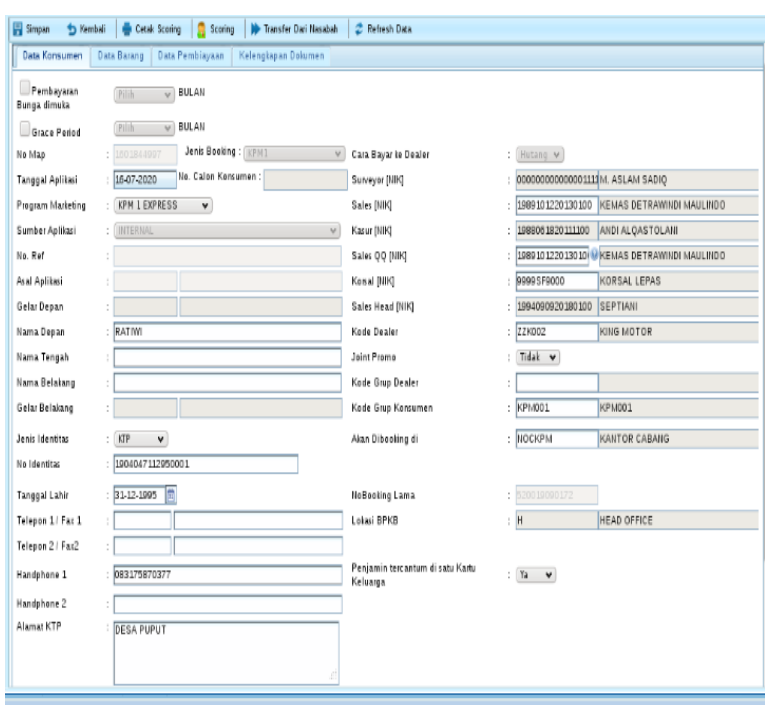

Gambar 6.Prototype entry nasabah

Antarmuka halaman Entry Nasabah pada Gambar 6 merupakan halaman yang tampil ketika pengguna menginput data-data nasabah.

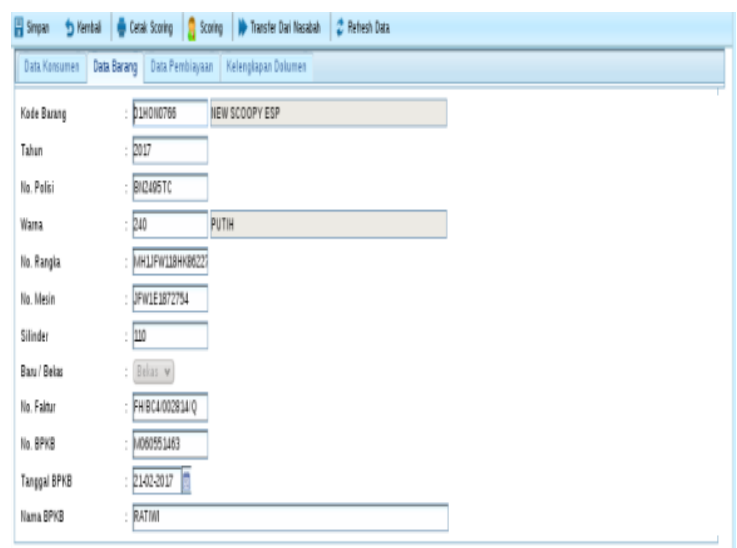

Gambar 7.Prototype entry barang

Antarmuka halaman Entry Barang pada Gambar 7 merupakan halaman yang tampil ketika pengguna menginput data Barang.

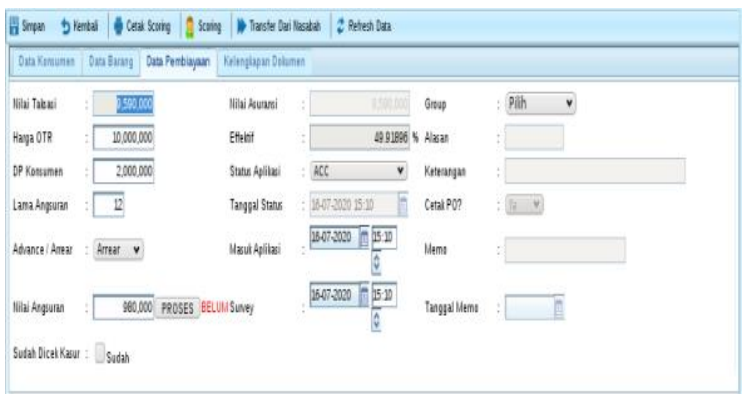

Gambar 8.Prototype Data Pembiayaan

Antarmuka halaman Pembiayaan pada Gambar 8 merupakan halaman yang tampil ketika pengguna menginput data konsumen, input DP, lama angsuran dan nilai angsurannya.

\section{Pengujian}

Pengujian dilakukan terhadap sistem yang telah dibangun. Pengujian ini bertujuan untuk membuktikan konsep dan sesuai kebutuhan pengguna dan hasil pengujian memberikan hasil yang sesuai dengan yang diharapkan.

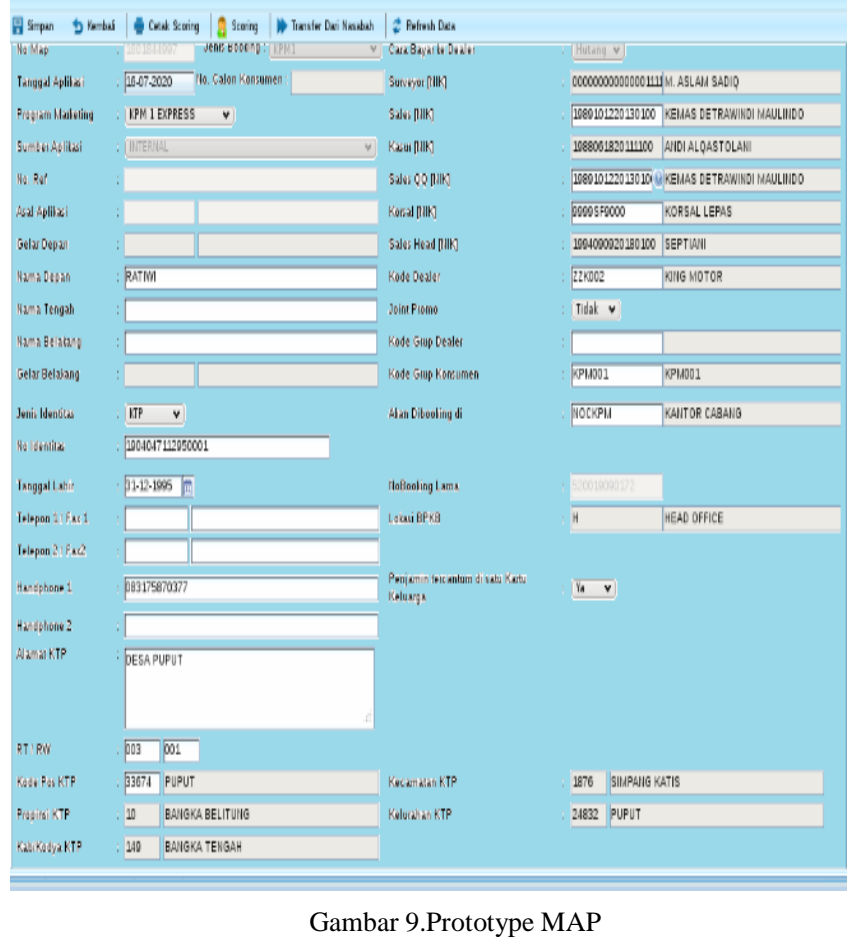

Antarmuka halaman Hasil Prototype MAP pada Gambar 9 merupakan halaman yang tampil ketika pengguna menginput data-data nasabah.

\section{KESIMPULAN}

Sebelum memasukkan data harus di lakukan pengecekan terhadap kebenaran informasi yang dihasilkan sesuai yang diinginkan dan mempersiapkan dukungan hardware dan software yang spesifikasinya dapat mendukung sistem ini dengan baik dalam melakukan back-up data untuk mengantisipasi agar tidak terjadi halhal yang tidak kita inginkan. Adapun hal lain yang dapat disimpulkan bahwa aplikasi yang dibuat dapat digunakan dalam membantu penggunaannya seperti bagian OPS(Oprationals), aplikasi akan membatu dalam penginputan berkas data konsumen. Adapun Prototype yang dibangun telah berhasil membantu MANDALA MULTIFINANCE dalam Penginputan MAP berbasis Web, Tampilan sistem masih perlu perbaikan lebih lanjut serta desain yang menarik., Analisa dan perancangan digambarkan menggunakan tool UML (Unified Modeling Languange).

\section{DAFTAR PUSTAKA}

[1] Sutabri, Tata. Analisa Sistem Informasi. Jakarta : Penerbit Andi, 2012

[2] Suhendra, dan Hariman Gunadi. Visual Modelling Menggunakan UML dan Rational Rose. Bandung : Informatika, 2009.

[3] Sarwindah, Sistem Penunjang Keputusan Pemilihan Perumahan Subsidi Berdasarkan Kebutuhan Konsumen dengan metode AHP. KNSI2018, pp. 668-673. 2018. 
[4] Komputer, Wahana. 2009. Panduan Praktis Microsoft Visio 2007. Yogyakarta: CV Andi Offset.

[5] Munawar, Pemodelan UML Berorientasi Objek. Jakarta : Andy Jogyakarta, 2007.

[6] F. K. S. Alexander. Kitab Suci Web Programming, MediaKom, Yogyakarta. 2011.

[7] N. Bunafit, Dasar Pemrograman Web PHP - MySQL Dengan Dreamweaver, GavaMedia, Yogyakarta, 2013.

[8] M. R.. Arief, Pemrograman Web Dinamis Menggunakan PHP dan MySQL, CV Andi, Yogyakarta, 2011.

[9] Sarwindah, Perancangan Sistem Informasi Tata Tertib Siswa Pada SMP Negeri 4 Kelapa Berbasis Dekstop.jurnal untan, 2014.

[10] Trianto, Eka \& Revina, Widya. Perancangan Sistem Iinformasi Pencatatan Pengiriman Barang di PT. TIKI Jalur Nugraha Ekakurir Cabang Bandung. Diakses pada 27 Febuari 2016.

[11] Dhika, H. Lukman \& Fitriansyah, A. (2015). Perancangan Web Jasa Pengiriman Barang. Diakses pada 27 Febuari 2016.

[12] Yakub, Pengantar Sistem Informasi Edisi 1, Yogyakarta: Graha Ilmu, 2012.

[13] D. P. Rini, Metodologi Pengembangan Sistem, Yogyakarta: Graha Ilmu, 2012.[5] Lukman, Wahyu. Pengertian Prototype.

[14] Edi Winarno, Ali Zaki, Pemrograman Web Berbasis Html 5, php, dan Javascript, Jakarta: Elex Media, 2014.

[15] R. S. Pressman, Software Engineering: A Practitioner's Approach 7 edition, McGraw-Hill Higher Education, 2009.

[16] Sarwindah, 2013. Kajian Pemilihan Software Desain Grafis Untuk Pembelajaran Dengan Metode AHP Pada SMK Muhamadiyah 9. SEMNASTEKNOMEDIA. 2013

[17] Whitten, Jeffrey L., Lonnie D. Bently, Kevin C. Dittman. System Analysis and Design Methods.New York : Mc Graw-Hill.

[18] O. Fajarianto, "Prototype Pelayanan Akademik Terhadap Komplain Mahasiswa Berbasis Mobile". JURNAL LENTERA ICT, Vol.3 No.1, Mei 2016 / ISSN 2338-3143,2016

[19] Syahrial, Sharipuddin, 2016, "Analisis Dan Perancangan Sistem Informasi Koperasi Berbasis Web Pada Koperasi Unit Desa Pandan Jaya Geragai". Jurnal Manajemen Sistem Informasi Vol 1 No. 1, September 2016 ISSN : 2540-8011 